\title{
Nano-Sized and Filterable Bacteria and Archaea: Biodiversity and Function
}

\author{
Lydia-Ann J. Ghuneim ${ }^{1 *}$, David L. Jones ${ }^{1}$, Peter N. Golyshin² and Olga V. Golyshina ${ }^{2}$ \\ ${ }^{1}$ School of Environment, Natural Resources and Geography, Bangor University, Bangor, United Kingdom, ${ }^{2}$ School \\ of Biological Sciences, Bangor University, Bangor, United Kingdom
}

\section{OPEN ACCESS}

Edited by:

Hongyue Dang,

Xiamen University, China

Reviewed by:

Laura Steindler,

University of Haifa, Israel

Konstantinos Ar. Kormas,

University of Thessaly, Greece

Matthias Labrenz,

Leibniz Institute for Baltic Sea

Research (LG), Germany

*Correspondence: Lydia-Ann J. Ghuneim

afp68e@bangor.ac.uk

Specialty section:

This article was submitted to

Aquatic Microbiology,

a section of the journal

Frontiers in Microbiology

Received: 26 March 2018

Accepted: 06 August 2018

Published: 21 August 2018

Citation:

Ghuneim L-AJ, Jones $D L$, Golyshin PN and Golyshina OV (2018) Nano-Sized and Filterable Bacteria and Archaea: Biodiversity and Function

Front. Microbiol. 9:1971. doi: 10.3389/fmicb.2018.01971
Nano-sized and filterable microorganisms are thought to represent the smallest living organisms on earth and are characterized by their small size $(50-400 \mathrm{~nm})$ and their ability to physically pass through $<0.45 \mu \mathrm{m}$ pore size filters. They appear to be ubiquitous in the biosphere and are present at high abundance across a diverse range of habitats including oceans, rivers, soils, and subterranean bedrock. Small-sized organisms are detected by culture-independent and culture-dependent approaches, with most remaining uncultured and uncharacterized at both metabolic and taxonomic levels. Consequently, their significance in ecological roles remain largely unknown. Successful isolation, however, has been achieved for some species (e.g., Nanoarchaeum equitans and "Candidatus Pelagibacter ubique"). In many instances, small-sized organisms exhibit a significant genome reduction and loss of essential metabolic pathways required for a free-living lifestyle, making their survival reliant on other microbial community members. In these cases, the nano-sized prokaryotes can only be co-cultured with their 'hosts.' This paper analyses the recent data on small-sized microorganisms in the context of their taxonomic diversity and potential functions in the environment.

Keywords: nano-sized microorganisms, ultramicrocells, filterable microorganisms, unculturable, oligotrophy, copiotrophy

\section{INTRODUCTION}

Recent technological advances in microbiology have helped to reveal the enormous diversity of prokaryotic life on our planet (Kuczynski et al., 2010; Caporaso et al., 2011; Thompson et al., 2017). While this has enabled us to characterize and map prokaryote populations across a diverse array of ecosystems, the functional role of most of these organisms remains unknown, due to our inability to culture, and study them in the laboratory. Nevertheless, using culture-independent approaches, e.g., metagenomics, many new candidate taxa that include nano-sized and filterable organisms have been discovered.

Nano-sized microorganisms are termed 'ultra-micro bacteria, 'ultra-micro cells,' 'dwarf cells,' 'ultra-small bacteria,' 'nanoorganisms,' 'nanobacteria,' nanoarchaea and 'nanobes' (Velimirov, 2001; Baker et al., 2010; Duda et al., 2012). The term nanoarchaea only relates to the phylum Nanoarchaeota (Huber et al., 2002), although it is commonly erroneously used within the literature. The exact definition of these terms is widely debated and no clear set of guidelines currently exists, however, it is considered that the microorganism must be in the "nano-range" (i.e., 50$400 \mathrm{~nm}$ ) in size. It should also be noted that in regards to aquatic systems, these ultra-small-sized organisms are not part of nanoplankton $(2.0-20 \mu \mathrm{m}$ in size), but instead reside in the picoplankton $(0.2-2.0 \mu \mathrm{m})$ or femtoplankton $(0.02-0.2 \mu \mathrm{m})$ communities (Sieburth et al., 1978; Fenchel, 1982; Azam et al., 1983). 
Previous studies have focused on detection of ultra-smallsized organisms in a wide range of environmental conditions including: acid mine drainage settings (AMD) (Baker and Banfield, 2003; Baker et al., 2006), glacial ice (Miteva and Brenchley, 2005), permafrost (Suzina et al., 2015), freshwater (Fedotova et al., 2012; Ma et al., 2016; Nakai et al., 2016), subterranean bedrock (Wu et al., 2015), hypersaline lakes (Narasingarao et al., 2012), the open ocean (Venter et al., 2004; Giovannoni et al., 2005; Glaubitz et al., 2013; Rogge et al., 2017), and the human body (Kajander and Ciftcioglu, 1998; Kajander et al., 2003; He et al., 2015). The predictions from genomic data from these environments suggest that there are many microorganisms that contain small genomes and either are present as free-living organisms or form a symbiotic relationship with other life forms, which adds another level of complexity to assess their functional role in the environment.

As the review of Duda et al. (2012) discusses a number of issues related with ultramicrobacteria, the aim of present review was to highlight the latest discoveries related to (1) taxonomic diversity, (2) biogeography, (3) current experimental approaches to characterize these organisms and (iv) potential role of ultra-small Bacteria and Archaea within a contrasting range of environments.

\section{Overview of Terminology}

When considering ultra-small or nano-sized organisms, it is important to note the significance of the terminology. There is no singular definition of what a nano-sized organism is (ultra-small bacteria, ultra-micro bacteria, nanobes, nanoforms, ultramicrocells, etc.) and consequently a variety of interpretations exists. Many of the terms are either synonymous, as in the case of ultra-small and ultra-micro (Velimirov, 2001), or can be classified as separate organisms, as in the case of nanobacterium and nanobe (Duda et al., 2012). Here, we consider three scenarios for their denotation (Figure 1).

The first scenario that these microorganisms originated from known species, whose cell size decreases over time due to either internal and/or external factors such as lack of nutrients or aging (Velimirov, 2001; Panikov, 2005; Duda et al., 2012). Such ability of bacteria and archaea to change size in response to external stress is a well-studied phenomenon. For example, under low nutrient conditions, Staphylococcus aureus reduced its size by 40\% (Watson et al., 1998; Chien et al., 2012), while the transfer of Pseudomonas syringae from laboratory culture media to plant leaves, induced the $50 \%$ reduction in cell size (Monier and Lindow, 2003). This size reduction is an attribute of dwarf cells, midget cells, ultra-small, ultramicro (Velimirov, 2001; Duda et al., 2012). For these cases, we advocate for the term 'ultramicrocells' sensu Duda et al. (2012).

The second scenario conjunctures that some distinct taxa, independently of growth conditions, nutrients' availability or age of their culture do constantly exhibit small cell sizes. One source describes these organisms in the following way:

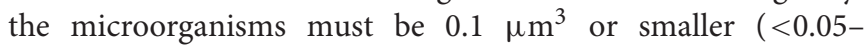
$0.40 \mu \mathrm{m}$ in diameter); the size must stay consistent under environmental stressors and life cycles; and finally, its genome size must be within the range 0.58-3.2 Mbp (Duda et al.,
2012). Under this definition, nano-sized microorganisms are associated with terms like ultra-small, ultramicro, nanoarchaea, nanoforms, nanoorgansims, and nanobacteria (Schut et al., 1995; Kajander and Ciftcioglu, 1998; Velimirov, 2001; Huber et al., 2002; Miteva and Brenchley, 2005; Panikov, 2005; Comolli et al., 2009; Duda et al., 2012; Fedotova et al., 2012; Luef et al., 2015; Giovannoni, 2017; Rogge et al., 2017). However, many standardsized microorganisms (i.e., cell volumes $>0.1 \mu \mathrm{m}^{3}$ ) also possess small genomes (1.5-2.0 Mbp) and would therefore fall into the 'ultra-small' category if based on these criteria alone.

The third scenario are microorganisms that have the ability to pass through membrane filter pores with small diameters $(0.45$ or $0.22 \mu \mathrm{m}$ ) despite having larger cell sizes (above the dimensions of 50-400 nm previously mentioned) (reviewed in Duda et al., 2012). This is often due to the absence of a rigid cell wall, which allows these microorganisms to effectively squeeze through small pores and as a result are commonly confused with nanosized or ultramicro-sized. 'Filterable' microorganisms is the most appropriate term to define such microorganisms.

In this review, a unified definition for nano-sized organisms is proposed. We define them as microorganisms that exhibit

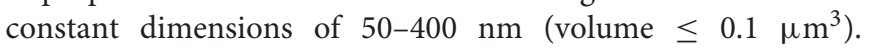
All microorganisms with synonymous names that fall under the definition provided are considered nano-sized organisms. Viruses and prions, which are smaller than $50 \mathrm{~nm}$ in size, are not considered to be living organisms (Figure $\mathbf{2}$ and Table 1). In aquatic systems, nano-sized organisms are a part of the picoplankton and femtoplankton communities, along with viruses (Sieburth et al., 1978; Venter et al., 2004; Tringe et al., 2005; Salcher, 2014).

\section{MICROBIAL ADAPTATIONS}

In the natural environments microorganisms use an arsenal of mechanisms to cope with, and adapt to, constantly changing physio-chemical conditions, through changes in their gene expression profile, physiology and morphology (Schut and Jørgensen, 2001; Chien et al., 2012). Here we highlight various survival strategies in prokaryotes, knowledge of which may stimulate future discoveries pertaining to small-sized organisms.

\section{Extreme Small Size}

In general, microorganisms do not fit into one standard model of size or shape (morphology) due to the impact environmental stressors (Young, 2006; Chien et al., 2012; Lever et al., 2015; Cesar and Huang, 2017). The efficiency of nutrients' uptake is dependent on organism size and the number of transporter systems on its surface (Button et al., 1998). Hence, in the case of cell size reduction, the surface area-to-volume ratio tends to increase (Figure 2). This, however, does not imply that the percentage of genes encoding membrane-bound proteins in genomes is higher in organisms with a larger surface area-tovolume ratio (Stevens and Arkin, 2000) (Figure 2).

Under conditions of starvation and energy limitations, microorganisms can drastically decrease in size, alter cellular morphology and motility to increase survivability (Torrella 


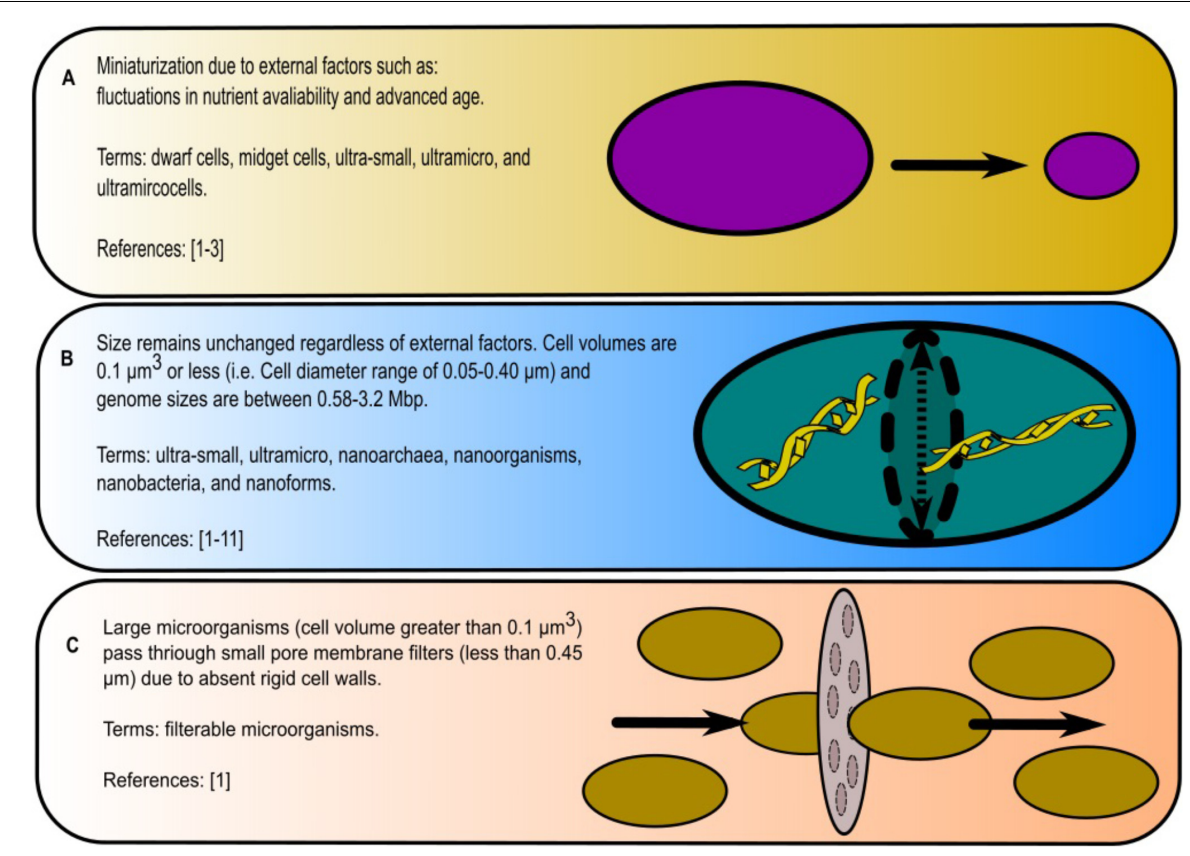

FIGURE 1 | Summary of definitions used to describe nano-sized organisms: (A) microorganisms shrinking in body size, (B) consistently small-bodied microorganisms and (C) large microorganisms that pass through filters. References are the following: [1] Duda et al., 2012; [2] Velimirov, 2001; [3] Panikov, 2005; [4] Schut et al., 1995; [5] Miteva and Brenchley, 2005; [6] Luef et al., 2015; [7] Huber et al., 2002; [8] Rogge et al., 2017; [9] Giovannoni, 2017; [10] Kajander and Ciftcioglu, 1998; [11] Fedotova et al., 2012.

and Morita, 1981; Lever et al., 2015; Cesar and Huang, 2017). For example, in low organic phosphate conditions, Caulobacter spp. increase their surface area to volume ratio by growing a prosthecae, stalk-like protrusions, in order to enhance organic phosphate uptake (Wagner et al., 2006; Lever et al., 2015). Another example is the species Sphingomonas alaskensis, which also undergoes morphological changes in response to the fluctuations in nutrients availability. In natural pelagic environment its body size is quite small (diameter: $0.2-0.5 \mu \mathrm{m}$; length: $0.5-3 \mu \mathrm{m}$ ) yet when grown on nutrient rich trypticase soy agar medium it increases in both diameter and length (diameter: 0.8; length: 2-3 $\mu \mathrm{m}$ ) (Vancanneyt et al., 2001; Lever et al., 2015).

\section{Lifestyle: Free-Living vs. Symbionts}

Nano-sized organisms are thought to contain genomes coding for a very limited number of functions and pathways, which is a characteristic commonly associated with symbionts, however, nano-sized organisms do also exist in a free-living state. Generally, symbionts do not have the means for their existence without relying on essential metabolites provided by the host. However, these organisms do thrive probably due to their highly specialized and unique functions which allows the host to be more competitive (McCutcheon and Moran, 2011). For instance, TM7 ("Ca. Saccharibacteria”) bacteria isolated from the human oral mucosa can effectively conceal its host, Actinomyces odontolyticus subsp. actinosynbacter XH001, from the human immune system response (He et al., 2015; further discussion in Section “TM7 Bacteria or "Candidiatus Saccharibacteria”").

\section{Oligotrophy and Copiotrophy}

Oligotrophs also known as K-strategists, are organisms that prefer low-nutrient environments (Schut et al., 1997; Panikov, 2005; Torsvik and Øvreås, 2008). One of the most wellcharacterized oligotrophic environments is the open ocean, which encompasses $90 \%$ of the biosphere (i.e., the sum of all the ecosystems) (Schut et al., 1997; Hansell et al., 2009). In this environment, many essential nutrients are only present in very low concentrations: iron at $0.2-1.38 \mathrm{nmol} \mathrm{kg} \mathrm{kg}^{-1}$,

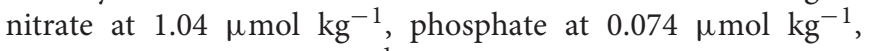
silicate at $3.2 \mu \mathrm{mol} \mathrm{kg} \mathrm{kg}^{-1}$, dissolved inorganic carbon at $11 \mu \mathrm{mol} \mathrm{kg} \mathrm{kg}^{-1}$, and dissolved organic carbon (DOM) at 40$80 \mu \mathrm{mol} \mathrm{kg}{ }^{-1}$ (Johnson et al., 1997; Roshan and DeVries, 2017; Sauzède et al., 2017; Tagliabue et al., 2017), which makes it difficult to mimic such conditions and obtain a detectable growth of these microorganisms in vitro. At such low concentrations of nutrients microorganisms lower their metabolic rates and become less capable of forming aggregates (i.e., colonies), as seen in many pelagic organisms, such as SUP05 group bacteria and in "Ca. Pelagibacter ubique" (see references below in Sections "SUP05 Group" and "Ca. Pelagibacter ubique"). Overall, oligotrophs are characterized by small cell sizes, which are more advantageous in low nutrients conditions. The correlation between oligotrophy and diminutive size appears almost ubiquitously (Giovannoni et al., 2014), however, few studies have detected ultra-small-sized microorganisms in high-nutrient systems, such as eutrophic aquifers or the human oral cavity (He et al., 2015; Luef et al., 2015). 


\section{Escherichia coli*}

Diameter $=1 \mu \mathrm{m}$

Length $=2 \mu \mathrm{m}$

$\mathrm{SA}\left(\mu \mathrm{m}^{2}\right)=6.28$

$\mathrm{V}\left(\mu \mathrm{m}^{3}\right)=1.3$

$\operatorname{SAN}\left(\mu \mathrm{m}^{2} / \mu \mathrm{m}^{3}\right)=4.8$

Total Number of Proteins $=4,319$

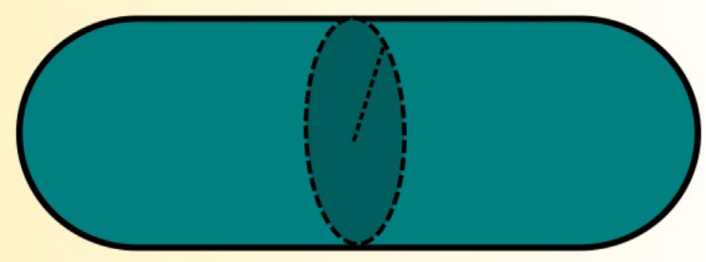

Membrane Proteins $=1,061(24.2 \%)$

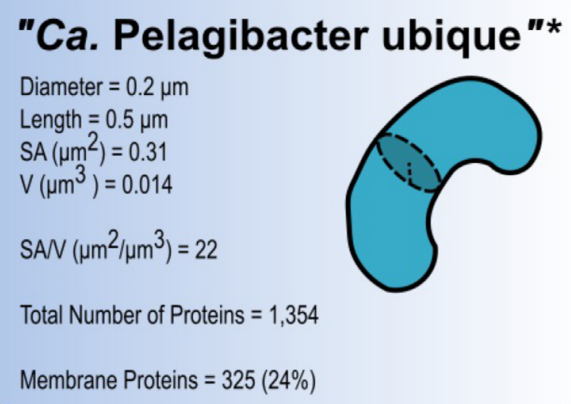

Nanoarchaeum equitans ${ }^{* *}$

Diameter $=0.4 \mu \mathrm{m}$

$\mathrm{SA}\left(\mu \mathrm{m}^{2}\right)=0.503$

$\mathrm{V}\left(\mu \mathrm{m}^{3}\right)=0.0335$

$\operatorname{SA} N\left(\mu \mathrm{m}^{2} / \mu \mathrm{m}^{3}\right)=15$

Total Number of Proteins $=536$

Membrane Proteins $=121(22.5 \%)$

FIGURE 2 | Surface area (SA) and volume (V) ratios in three selected species of different sizes: Escherichia coli, "Candidatus Pelagibacter ubique," and Nanoarchaeum equitans. The microorganism with the smallest dimensions ("Ca. P. ubique") had the largest ratio at 22. The habitat of "Ca. P. ubique" is the open ocean (oligotrophic environment) and hence its high SAN ratio is advantageous to living in low nutrient conditions. The total protein numbers in encoded by genomes of E. coli (NCBI Reference Sequence: NC_000913.3), "Ca. P. ubique” (GenBank: CP000084.1), and N. equitans (GenBank: AE017199.1) are given and related with the proteins with membrane-spanning domains. For prediction of transmembrane helices in proteins, above genomes were analyzed using TMMHMM 2.0 Server at http://www.cbs.dtu.dk/services/TMHMM/ (Krogh et al., 2001; Möller et al., 2001). *Dimensions and calculations of surface area and volume were obtained from Young (2006). **The diameter was obtained from Huber et al. (2002), the equations for the surface area (SA $=4 \pi r^{2}$, where $r$ is the radius) and volume $\left(V=\frac{4}{3} \pi r^{3}\right.$, where $r$ is the radius) of a sphere.

Copiotrophs or R-strategists, are active, fast-growing with larger cell body sizes, usually motile organisms well-suited to nutrient-rich environments; they represent the majority of bacteria and archaea cultured up to date (Dang and Lovell, 2016; Giovannoni, 2017). Despite being easy to culture, copitotrophs appear as rarer taxa in natural environments. They take advantage of sporadic high nutrients concentrations which in turn may transiently cause a rapid population growth (Vergin et al., 2013; Dang and Lovell, 2016). It is thought that copiotrophs are not nano-sized organisms as an increased surface areato-volume ratio is not necessarily advantageous in nutrientrich environments (Martínez-Cano et al., 2015). However, copiotrophic bacteria also tend to reduce their sizes as a response to starvation conditions in an attempt to increase their surface area-to-volume ratio, as in the case of $S$. aureus (40\% reduction in size) and $P$. syringae (50\% reduction in size) (Watson et al., 1998; Monier and Lindow, 2003).

\section{CHARACTERIZATION}

Due to the constraints in accurately mimicking environmental settings in vitro, the cultivation of small organisms is often problematic and represents a main bottleneck in the process of their phenotypic characterization. In order to predict functional traits of nano-sized microorganisms as a part of the microbial community, culture-independent techniques are currently employed as primary approaches, as stand-alone or combinations of approaches: metagenome sequencing, flowcytometry and fluorescence microscopy. Below is a brief overview of some culture-independent techniques and the challenges that arise when attempting to isolate nano-sized microorganisms.

\section{Metagenomics}

As indicated above, metagenomics has played a central role in attempts to detect small-sized and filterable organisms and elucidate their functions. In turn, the isolation and characterization of nano-sized organisms has yielded, and to some extent, validated new genomic data (Huber et al., 2002; Giovannoni et al., 2005). In many of the large-scale metagenomics studies, the significant proportion of assembled genomes exhibited small sizes (Rappé et al., 2002; Venter et al., 2004). In particular, an in-depth investigation of the SAR11 clade led to the discovery of "Ca. Pelagibacter ubique," a ubiquitous and predominant marine bacterium (Giovannoni, 2017; Zhao et al., 2017). Also, microbial communities in the deep biosphere proved to be more diverse than previously anticipated, with a plethora of miniature cells with small genomes (Wu et al., 2015). Finally, hypersaline lakes, a good model for extreme habitats, 


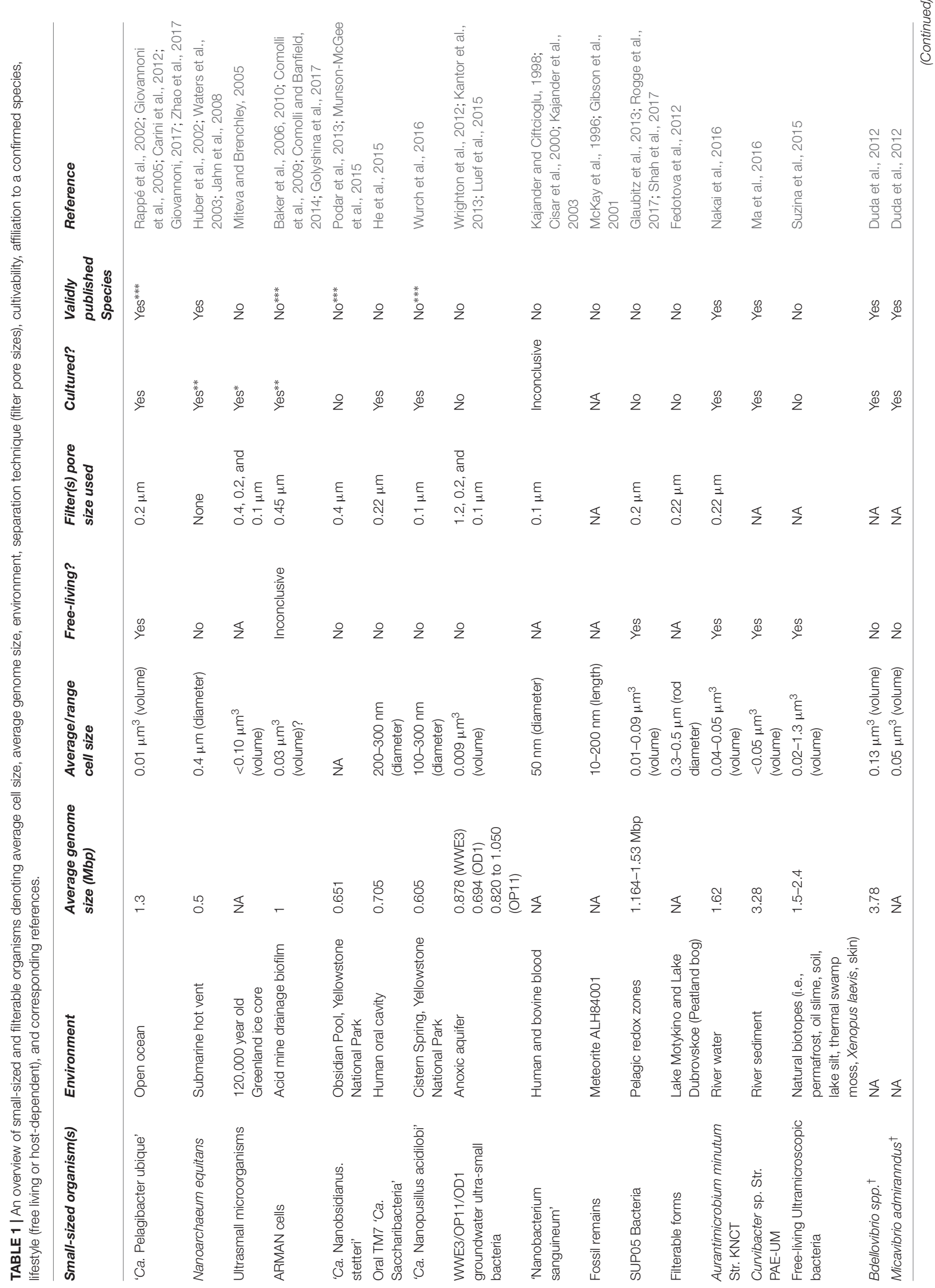


were found to contain filterable cells, about $0.6 \mu \mathrm{m}$ in diameter, that were termed " $\mathrm{Ca}$. Nanohaloarchaeota" (Narasingarao et al., 2012). This study was in large facilitated by a more targeted sample preparation (filtration) procedure and de novo sequencing approach. However, we must note that small genomes and the ability to pass via $0.1,0.22$, and $0.45 \mu \mathrm{m}$ pore-size filters are not necessarily the evidence of small sizes of microorganisms (i.e., filterable microorganisms), for instance, the symbiont "Ca. Tremblya princeps" has an extremely reduced genome of $0.13 \mathrm{Mbp}$, yet, examination by microscopy showed its length to be ca. $2.3 \mu \mathrm{m}$ (McCutcheon and Moran, 2011).

\section{Flow Cytometry and FACS Cell Sorting}

The further culture-independent techniques, flow cytometry (Gasol and Morán, 1999; Miteva and Brenchley, 2005; Wang et al., 2007; Neuenschwander et al., 2015) and fluorescence in situ hybridization (FISH) (Glaubitz et al., 2013; Munson-McGee et al., 2015; Neuenschwander et al., 2015) have been widely used to study microbial populations in their natural environments. In combination with fluorescence probes targeting SSU rRNA or immunolabeling cellular proteins, this approach allows quantification of a certain taxonomic group of microorganisms (Neuenschwander et al., 2015). Combining FISH/CARDFISH (Fluorescence in situ Hybridization/Catalyzed Reporter Deposition-Fluorescence in situ Hybridization) and flow cytometry (also known as 2C-FISH) allowed for sorting and obtaining relatively pure populations of microorganisms, as it was the case of LD12 clade of ultramicrobacteria from freshwater. These ultramicrobacteria were known to be very difficult to isolate and characterize due to their small genomes and hence limited metabolic repertoires, cell sorting was therefore the crucial starting point for their subsequent genomic studies (Salcher et al., 2013; Neuenschwander et al., 2015). Although improvements in individual techniques were achieved in this study, the methodology of sample preparation is still tedious and time-consuming with relatively limited yields of cells (Neuenschwander et al., 2015). Whatever the case, the applications of cell sorting have been successful in resolving a number of "single-cell-genomes" (Ishoey et al., 2008; Probst et al., 2018).

\section{Isolation of Nano-Sized Microorganisms}

Although isolation is an essential step in characterizing organisms, it is often overlooked and traditional approaches to culture them frequently prove unsuccessful. Many of the studies presented in this review employed filtering through 0.1$1.2 \mu \mathrm{m}$ pore size filters to facilitate enrichment and isolation (Table 1). The exception to the filtration methodology was Nanoarchaeum equitans, which was co-cultured with the host, Ignicoccus hospitalis, and then separated out via centrifugation (Huber et al., 2002; Waters et al., 2003). Conversely, while the target microorganisms may be small enough to pass through the membrane, certain larger organisms can squeeze through pores, due to a lack of rigidity of their cells. Another example of organisms squeezing through small-sized pores are archaea of families Ferroplasmaceae $(0.2-3 \mu \mathrm{m}$ in diameter in average) and Thermoplasmataceae (0.5-3 $\mu \mathrm{m}$ in length and $0.2-0.5 \mu \mathrm{m}$ thick), 
that can easily pass through a $<0.45 \mu \mathrm{m}$ pore filter due to the lack of a rigid cellular envelope (Golyshina, 2014; Nagy et al., 2016).

In previous studies, along with 'small-sized-organisms', many other microorganisms have been co-isolated (Venter et al., 2004; Tringe et al., 2005; Garza and Dutilh, 2015). An extra level of authentication is therefore necessary to reliably confirm the existence and metabolic function of these organisms, e.g., through an improvement in isolation and culturing techniques. Small cell size is the only certainty related to nano-sized organisms that belong to a range of taxa and do not share a common metabolism. For their characterization, a prior genomic analysis of the source community is critical. This would allow the targeting, e.g., organism-specific surface proteins to enable FACSor immunoprecipitation-based techniques targeted organisms of interest.

\section{NANO-SIZED AND FILTERABLE MICROORGANISMS}

Though the different characterization techniques as mentioned above, the story of ultra-small microorganisms and our understanding of their ecosystem functioning is rapidly evolving. Here, some of the major milestones are outlined in regards to successful isolation and characterization of a variety of nanosized organisms. Further, we have summarized the data on various microorganisms covered in this section in Figure 3 and Table 1.

\section{Rise of the Very Small}

Although ultramicrobacteria have been known for a long time (Oppenheimer, 1952), the subject laid dormant for a number of years. This was in part due to the limitations in microbiological techniques, and the lack of knowledge of their physiology and metabolism. That changed when McKay et al. (1996) first claimed their existence in Martian rocks. Not only did this imply that life may exist on exoplanets, but it also challenged the ideas on lower limit of size of a lifeform (McKay et al., 1996; Gibson et al., 2001). It was suggested that the smallest free living organism must be in the spherical diameter range of $250-300 \mathrm{~nm}$ to properly contain the $250-300$ proteins essential to life (including the ribosomal proteins), although it was also suggested that, theoretically, a primitive organism can be as small as $50 \mathrm{~nm}$ (Kajander and Ciftcioglu, 1998). This was similar to an earlier study by Mushegian and Koonin (1996) who hypothesized that the minimal number of genes required for life ranges between ca. 250-450, however, there was no consensus on the number of ribosomal proteins that were actually needed. Importantly, it was never established in the McKay et al. (1996) study whether these nano-scale objects were free-living organisms, nor was it confirmed that these objects were living at all.

\section{Nanoarchaeum equitans}

Huber et al. (2002) found that a new archaeal species, I. hospitalis, isolated from hot submarine vents, had in its culture a companion of a small cell size. The new phylum Nanoarchaeota and corresponding species $N$. equitans were described as the first nano-sized archaea. The genome analysis revealed that it contained a chromosome of only 0.5 Mbp (Huber et al., 2002), while electron and fluorescence microscopy suggested that the cells of $N$. equitans were ca. $400 \mathrm{~nm}$ in diameter and were attached to the cell surface of its host, I. hospitalis. Further, it was shown that $N$. equitans was incapable of growing without its host, which in contrary neither benefited or was impaired by $N$. equitans (Huber et al., 2002; Jahn et al., 2008). The inability of N. equitans to survive without its host is reflected in its small streamlined genome, which was a result of massive gene losses (Huber et al., 2002) including those for key biosynthetic pathways for vitamins, cofactors and amino acids (Torrella and Morita, 1981; Mushegian and Koonin, 1996; McCutcheon and Moran, 2011).

\section{"ARMAN" Cells}

"ARMAN" (Archaeal Richmond Mine Acidophilic Nanoorganism) were first detected through de novo shotgun sequencing of aqueous sample obtained from an acid mine drainage (AMD) system and not through standard PCR-based surveys (Baker et al., 2006). Subsequent cryo-TEM analysis revealed an accumulation of filterable cells that were $0.03 \mu \mathrm{m}^{3}$ in volume with clearly defined cell walls (Comolli et al., 2009). "ARMAN" cells were initially considered free-living, possibly slow-growing, organisms possessing some intracellular tubular structures (Comolli et al., 2009), however, later on, their ability to free-living lifestyle was questioned (Comolli and Banfield, 2014).

According to the metagenome analysis with almost fully assembled "ARMAN" genomes of ca. $1 \mathrm{Mbp}$ in size and proteomics, these organisms contain a rather unique set of genes with $45 \%$ of the genes failing to match to a known biological function, while $63 \%$ of the proteins identified could not be assigned to known archaeal protein families (Baker et al., 2010). Due to the small sizes of their genomes, it was assumed that "ARMAN" cells are certainly dependent on other community members, being either symbionts or commensals (Baker et al., 2010).

Cultivation of an "ARMAN"-related organism, 'Ca. Mancarchaeum acidiphilum' Mia14 revealed that it was dependent on its host, euryarchaeon Cuniculiplasma divulgatum (Golyshina et al., 2017). As in the above examples, Mia14 underwent streamlining of its genome $(0.95 \mathrm{Mbp})$ due to the massive gene loss. Similarly, it exhibits significant voids in its biosynthesis of amino acids, CoA, NAD and NADP, vitamins and heme. Additionally, its central metabolism lacks glycolysis and gluconeogenesis, pentose phosphate pathway and tricarboxylic acid cycle (Golyshina et al., 2017). Interestingly, Mia14 cell sizes were only marginally smaller than Cuniculiplasma cells, which were $0.1-2 \mu \mathrm{m}$ in size (Golyshina et al., 2016).

\section{Other Archaea}

"Candidatus Nanobsidianus stetteri" Nst1, a member of phylum Nanoarchaeota was first reported after the single-cell isolation alongside its host from the order Sulfolobales (phylum Crenarchaeota) by Podar et al. (2013). Unlike N. equitans, which is associated with a single host species, I. hospitalis, "Ca. N. stetteri" can use a multitude of Sulfolobales species as hosts. Its genome was ca. 20\% larger than that of N. equitans and possessed 


\begin{tabular}{|ll|}
\hline 'Ca. Pelagibacter ubique' & \\
Nanoarchaeum equitans & \\
Ultrasmall Microorganisms \\
ARMAN cells \\
'Ca. Nanobsidianus stetteri"(no dimensions found) & \\
Oral TM7 & \\
'Nanopusillus acidilobi' \\
WWE3/OP11/OD1 groundwater ultra-small bacteria \\
'Nanobacterium sanguineum' \\
Fossil remains \\
Escherichia coli* \\
Enterobacteria phage T4* \\
SUP05 Bacteria \\
Filterable forms \\
\\
Dimensions (with references) are reported in Table 1 \\
*Size guides
\end{tabular}

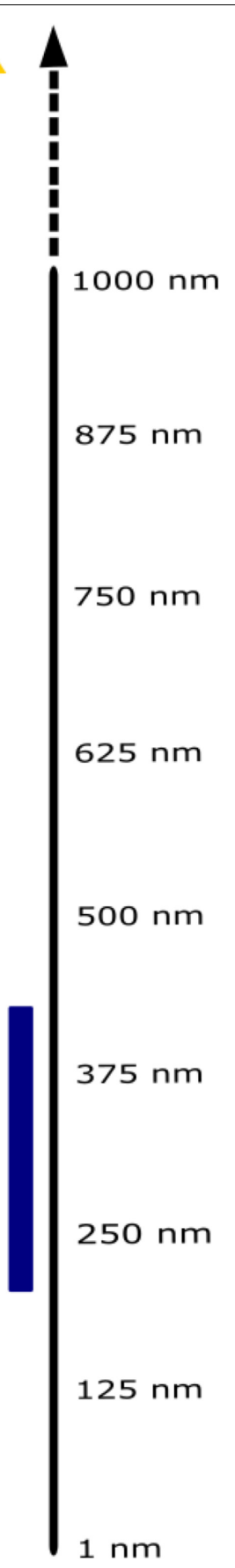

FIGURE 3 | Size comparison of nano-sized organisms. Each of the colored lines represents relative range of sizes (in one dimension) of each individual. References and numerical ranges for individuals can be found in Table 1. If size was reported with volume, the organism was assumed to be spherical and then obtained the radius with the equation, $V=\frac{4}{3} \pi r^{3}$, where $r$ is the radius. * References for size guides: Escherichia coli (approximately $\left.1 \mu \mathrm{m} \times 2 \mu \mathrm{m}\right)$ and phage T4 (approximately $90 \mathrm{~nm} \times 200 \mathrm{~nm}$ ) (Leiman et al., 2003). 'Ca. Nanobsidianus stetteri' has no available information concerning cellular dimensions.

a complete gluconeogenesis pathway (Podar et al., 2013; Munson-McGee et al., 2015). The genome analysis also indicated that "Ca. N. stetteri" genome coded for cellular functions previously not associated with the Nanoarchaeota taxon; the study concluded that these archaea share a common ancestor with N. equitans (Podar et al., 2013; Munson-McGee et al., 2015).
Another study (Munson-McGee et al., 2015) has partially resolved two further single-cell genomes of "Nanobsidianus"related archaea from Yellowstone hot springs and suggested their close relatedness with " $\mathrm{Ca}$. N. stetteri" Nst1, but pointed at their association with archaea of "Acidicryptum spp." of Sulfolobales. "Ca. Nanopusillus acidilobi" is another success 
story, where this small-sized, reduced-genome archaeon was cocultured with its host, Acidilobus sp. A7 by Wurch et al. (2016). "Ca. Nanopusillus acidilobi" is a thermophilic ectosymbiont, much like N. equitans and "Ca. Nanobsidianus stetteri." This particular species is only marginally smaller in body size than $N$. equitans (approximately $100-300 \mathrm{~nm}$ in diameter), both share approximately $80 \%$ SSU rRNA gene sequence identity (and 97-98\% with 'Ca. Nanobsidianus stetteri'), and exhibit much of the same functions as judged from genomic data (Wurch et al., 2016). "Ca. Nanopusillus acidilobi" genome possesses no genes related to respiration, ATP synthesis and cannot produce its own amino acids, lipids, nucleic acids, and co-factors. Genomic data suggests that, like in its relative, "Ca. N. stetteri," glycogen may serve as a storage compound and facilitate its short-term energetic independence from the host (Wurch et al., 2016). A high density of "Ca. Nanopusillus acidilobi" on the surface of its host Acidilobus sp. 7A, deficiency of its genome in genes for central metabolic, biosynthetic and energy-generating pathways suggest a commensal or ectoparasitic lifestyle of these nanoarchaea (Wurch et al., 2016). Expression of flagellar proteins reported in proteomic data further suggests that " $\mathrm{Ca}$. Nanopusillus acidilobi" has the ability to migrate from one host to another (Wurch et al., 2016).

\section{"Ca. Pelagibacter ubique"}

While the existence of oceanic ultramicrobacteria has been welldocumented, obtaining them in a pure culture remained difficult. Earlier studies (Morris et al., 2002; Rappé et al., 2002) revealed a very abundant clade of Alphaproteobacteria, SAR11, which makes up to $25 \%$ of plankton in the open ocean and is represented by small-sized, simple-metabolism bacteria (Giovannoni, 2017). Initially found in pelagic water sampled from the Sargasso sea, these bacteria termed "Ca. Pelagibacter ubique" had genomes of approximately $1.3 \mathrm{Mbp}$ and are considered to be one of the smallest free living cells (Giovannoni, 2017; Zhao et al., 2017). Their genomes contained the necessary gene sets for producing all 20 amino acids as well as other essential biosynthetic pathways (Giovannoni et al., 2005; Carini et al., 2012). Subsequent studies indicated that " $\mathrm{Ca}$. P. ubique" required an unconventional medium, which was composed of methionine, glycine, pyruvate, and artificial seawater (Carini et al., 2012).

It was also found that " $\mathrm{Ca}$. P. ubique" had a rather unique metabolism because of its ability to use glycolate instead of glycine at low glycine concentrations. Glycolate can be used in glycine biosynthesis through glyoxylate amination, with the glycine consequently being used for serine biosynthesis (Carini et al., 2012; Tripp, 2013). The glycolate to serine pathways are regulated by two glycine riboswitches, the first of which controlling the glyoxylate to glycine biosynthesis and the second regulating the glycine to serine biosynthesis. At low glycine concentrations, the first riboswitch is turned on to produce more glycine (Tripp, 2013). When there are ample amounts of glycine in the cell, the first riboswitch turns off the glycine biosynthesis and the second riboswitch induces the conversion of glycine to serine. The ability to use glycolate instead of glycine to further create serine may be an evolutionary response to relative excesses of glycolate formed by phytoplankton in carbon limited conditions (Carini et al., 2012). As a free-living organism, "Ca. P. ubique" has the ability to adapt to changing conditions fairly well-despite having a streamlined genome. It also challenged the previous assumption that small genome sizes were restricted to symbiotic organisms (Huber et al., 2002; Giovannoni, 2017).

\section{SUP05 Group}

Oxygen-depleted zone in pelagic systems with dissolved oxygen concentrations below $60 \mu \mathrm{mol} \mathrm{kg}{ }^{-1}$ present a unique challenge to organisms moving through the transition zone from high to low nutrient availability (Glaubitz et al., 2013; Rogge et al., 2017). According to cell counts from flow cytometry, SUP05 bacteria are a common bacterioplankton component in depleted oxygen zones (Glaubitz et al., 2013; Rogge et al., 2017). As chemolithoautotrophic organisms, they metabolize sulfur compounds and play a key role in the carbon, sulfur and nitrogen cycles to facilitate life in the redoxclines across the globe (Glaubitz et al., 2013; Rogge et al., 2017; Shah et al., 2017). They have the ability to carry out denitrification and uptake carbon dioxide in pelagic low oxygen zones, which is supported by genomic predictions, radioisotopic data and cultivation attempts (Glaubitz et al., 2013; Rogge et al., 2017; Shah et al., 2017). Cultivation attempts of one of the members of the SUP05 group, "Candidatus Thioglobus autotrophicus," revealed the utilization of ammonium under anaerobic conditions and nitrite production (Shah et al., 2017). Studies on the SUP05 group have suggested cellular volumes ranging within $0.01-0.09 \mu^{3}$ and a genome of 1.164-1.53 Mbp, which indicates that these bacteria have undergone streamlining in their evolutionary past, much like "Ca. P. ubique" (Rogge et al., 2017; Shah et al., 2017).

\section{Filterable Forms in Peatland Bogs}

Despite the abundance of organic carbon in aquatic subsystems of peatland bogs, its mineralization is very slow due to the elevated concentrations of phenolic compounds causing acidification $(\mathrm{pH}$ 4.4-4.8), enzyme inhibition and nitrogen limitation (Fedotova et al., 2012). This is the case for sphagnum peatland bogs in northern Russia, that contain a high number of filterable bacteria and archaea, $1.69 \pm 0.53 \times 10^{4}$ and $3.16 \pm 0.43 \times 10^{4}$ cells $/ \mathrm{mL}$, correspondingly (Fedotova et al., 2012). Phylogenetic analysis of 16S rRNA genes shows they were derived from several phyla (Fedotova et al., 2012). One-third of the archaeal sequences had a high identity (94-99\%) with representatives of the orders Methanobacteriales and Methanosarcinales, while the rest exhibited a distant relatedness $(71-74 \%$ sequence identity) to cultured methanogens and collectively belonged to the LDS (Lake Dagow sediment) cluster (Glissmann et al., 2004). All detected bacterial species had high SSU rRNA gene sequence identities (94-99\%) to the Betaproteobacteria, Gammaproteobacteria, Alphaproteobacteria, and Actinobacteria, which confirms that small size is an adaptation to low nutrient conditions common across the broad range of higher taxa. The study also attempted to culture filterable microorganisms on solid media: from the total microscopic cell count numbers, only a fraction of approximately $0.5-1.2 \%$ did form colonies 
represented by bacterial genera Mesorhizobium, Bradyrhizobium, Sphingomonas, and Agrobacterium. A major discrepancy between the SSU rRNA amplicon libraries sequences of microbial communities in those freshwater samples and the taxonomy of cultured bacteria was also observed (Fedotova et al., 2012).

\section{Ultra-Small Bacteria From Greenland Ice}

Glacial ice presents a rather unique challenge to many microbial species due to its sub-zero temperatures and oligotrophic conditions and is considered a freshwater-like habitat for microorganisms (Hodson et al., 2008). It has been previously noted that a number of ultrasmall organisms have been detected in several ice cores (Miteva, 2008). A plethora of bacteria in 120,000 year-old Greenland ice, which, after melting the ice cores, passed through filters with pore sizes of $0.4,0.2$, and even $0.1 \mu \mathrm{m}$ was detected (Miteva and Brenchley, 2005). Scanning electron microscopy and flow cytometry confirmed that the filtration methodology was effective at removing larger cells residing in the melted ice water. The authors also stated that a considerable amount of fungal colonies were also present, although these were not discussed in further detail (Miteva and Brenchley, 2005), however, one can assume those were derived from filterable fungal spores. It is not clear if all $>1,200$ cultured bacteria were ultra-small, as there was evidence of larger organisms (e.g., spores of fungi and of Firmicutes), which possibly were cultured due to the non-uniform sizes of filter pores, over-pressurizing filtration units or non-rigid cell envelops of microorganisms that allowed them passing through filters (Wang et al., 2007, 2008). Whatever the case, the study of Miteva and Brenchley (2005) clearly demonstrated the viability in and cultivability of very small microorganisms with experimentally measured average volumes ranging between 0.043 and $0.1 \mu \mathrm{m}^{3}$ from, a polar ice environment.

\section{WWE3, OD11, and OP1 Candidate Phyla of Ultra-Small Bacteria From Groundwater}

Much of the bacterial species discussed so far have been identified in oligotrophic environments, however, ultra-small organisms are not exclusive to these habitats. The WWE3OD11-OP1 candidate phyla of groundwater bacteria were found in an eutrophic environment (Luef et al., 2015). Although these bacteria have not been cultivated, ultra-small cells have been successfully imaged challenging previous ideas on possible habitats of these organisms.

Luef et al. (2015) described the cellular structures present within ultra-small-sized-organisms: using cryo-TEM images they identified pili, cell walls, cellular division, and the presence of viruses. The study investigated the freshwater collected from an anoxic, organic carbon rich groundwater located several meters below the surface. Until that point, small-sized microorganisms were thought to be either associated with oligotrophic conditions or microbial communities with a reduced diversity, e.g., AMD. Importantly, it appears that small size can also be beneficial in other environments. The study was unable to successfully perform CARD-FISH on the proposed ultra-small cells (Luef et al., 2015) and therefore could not confirm that small cells seen were indeed of the candidate phyla that they reported on.

Metagenomic analyses by Wrighton et al. (2012) and Kantor et al. (2013) have revealed that WWE3, OP1, OD11, TM7, and SR1 candidate phyla of bacteria possessed small genomes, lacked genes for several essential metabolic processes and contained genes of both archaeal and bacterial origin. The genomic predictions inferred that WWE3, OP1, and OD11 candidate phyla are capable of growing in organic carbon-rich environments (Wrighton et al., 2012; Kantor et al., 2013; Luef et al., 2015). The RuBisCO (type II/III ribulose-1, 5-biphosphate carboxylase-oxygenase), which was predicted in these groundwater ultrasmall bacteria, is not likely to be involved into the classical CBB (Calvin-BensonBassham) pathway, but into the $\mathrm{CO}_{2}$ fixation linked with the AMP (adenosine monophosphate) recycling for ultimate ATP (adenosine triphosphate) production, similarly to the type III archaeal RuBisCo (Wrighton et al., 2012; Kantor et al., 2013). The occurrence of this pathway suggests that these organisms are not restricted to oligotrophic environments, but can survive with higher levels of available nutrients.

\section{TM7 Bacteria or "Candidatus Saccharibacteria"}

Recent studies have shown that nano-sized organisms can also be a component of the human microbiome. A member of the bacterial candidate phylum TM7 ("Ca. Saccharibacteria") was cultivated and co-isolated with A. odontolyticus subsp. actinosynbacter strain XH001 by $\mathrm{He}$ et al. (2015). Having spherical cells of 200-300 $\mathrm{nm}$ in diameter and a genome of $0.705 \mathrm{Mbp}$, this bacterium of phylotype TM7 (strain TM7x) is associated with human oral microflora and was found to have a rather unique lifestyle. Like many of others discussed here, it is dependent on its basibiont, the host of the epibiont, an organism that resides on the surface of the host, A. odontolyticus subsp. actinosynbacter XH001. Under normal conditions, TM7x is an obligate epibiont, but during starvation it changes its lifestyle to parasitic, which eventually kills its own host and which is not usual for oral microorganisms (He et al., 2015). Additionally, TM7x lacks the ability to produce its own amino acids which further suggests its dependence on A. odontolyticus subsp. actinosynbacter XH001 (He et al., 2015). Its relationship with the host is thought to exacerbate oral mucosal diseases by concealing host immune responses by inhibiting $A$. odontolyticus XH001-induced TNF- $\alpha$ mRNA expression in macrophages ( $\mathrm{He}$ et al., 2015). However, not all Candidate phylum TM7 members reside in the oral mucosa like TM7x: for example, RAAC3 with a small $(0.845 \mathrm{Mbp})$ genome was originally found in a sediment obtained from an acetate-stimulated aquifer (Kantor et al., 2013). Another representative of TM7 group, "Candidatus Saccharimonas aalborgensis," with the genome of $1.0 \mathrm{Mbp}$ was obtained from the activated sludge bioreactor (Albertsen et al., 2013; He et al., 2015). It remains unclear why TM7x has a more streamlined genome than the other phylotypes, a possible 
explanation of this adaptation is its specific human microbiome habitat and its complete dependency on its actinomycete host.

\section{SELECTIVE PRESSURES FOR SMALL SIZE}

An important conclusion that can be made from the aforementioned studies on small-size microorganisms is that their sizes and distribution are a direct consequence of nutrient availability. As mentioned previously, increasing the surface area-to-volume ratio, which is an attribute of smaller cells, provides microorganisms with the ability to take up nutrients more efficiently (Giovannoni et al., 2014). Both symbiotic and free-living organisms seem to have benefited from this change. The results from existing studies suggest that in environments with high nutrient concentrations, a nano-sized organism will likely be a symbiont (or epibiont) with a decreased cell size being a result of limited metabolic capabilities with complete metabolic dependence on a host (Martínez-Cano et al., 2015). N. equitans is a good example of this, as hydrothermal vents are relatively nutrient-rich, but these archaea are completely dependent on I. hospitalis (Giannone et al., 2014). As nutrients become less available, the more likely the small-sized organism will be free-living because an increased surface-area-to-volume ratio is incredibly advantageous under such conditions (Martínez-Cano et al., 2015). The species "Ca. Pelagibacter ubique" is a good illustration of this scenario. Residing in the nutrient-depleted open ocean, it needs to produce its own essential amino acids, vitamins, etc. to survive (Carini et al., 2012). This raises the question, as to why this typical adaptation (small size and limited metabolic capabilities) does also exist in relatively stable nutrient-rich habitats. One possibility is that there may be selective pressures coming from predatory species, especially in aquatic systems (Pernthaler et al., 2001; Simon et al., 2002; Pernthaler, 2017). In the study of Pernthaler et al. (2001), the presence of the protozoan, Ochromonas sp., resulted in an increasing population of members of Actinobacteria cluster Ac1. When an alternate protozoan predator, Cyclidium glaucoma, was introduced, no increase in population densities of Ac1 bacteria was observed (Pernthaler et al., 2001). Apparently, Ochromonas sp. prefers preys that are $0.8-4 \mu \mathrm{m}$ in size, while C. glaucoma prefers those smaller than $0.8 \mu \mathrm{m}$. Since the Acl are smaller than $0.8 \mu \mathrm{m}$, the presence of only Ochromonas sp. allowed them to proliferate (Pernthaler et al., 2001). It was later found that some isolates of Ac1 were in fact ultramicro-sized (less than $0.1 \mu \mathrm{m}^{3}$ volume) and this small size prevented them from predation by Ochromonas sp. strain DS (Hahn et al., 2003). Hence, large populations of small organisms may also be a response to, or the result of, protozoan grazing (Salcher, 2014).

Another driver of selection of particular organisms in the environment are viruses and phages. Phages are host-specific and in most cases infect highly populous and dense bacterial subpopulations, which allows for less competitive (e.g., slowgrowing) cells to proliferate (Winter et al., 2010; Salcher, 2014). Lysis of infected cells releases nutrients into the environment and makes them available to other community members allowing for overall microbial population growth (Weinbauer, 2004; Salcher, 2014). Viruses, similarly to predators, act as population control by culling overpopulated microorganisms ("killing the winner") while providing nutrients in the form of lysed cells to other species in the community (Weinbauer, 2004; Winter et al., 2010; Salcher, 2014).

\section{FUNCTIONAL ROLE OF SMALL-SIZED ORGANISMS}

As documented here, small-sized organisms are not characterized by any specific type of metabolism or taxonomic affiliation. Therefore, we assume that their functional role is not restricted and may highly vary depending on the environment and actual physio-chemical conditions. Aquatic systems are incredibly complex, as fluctuations between high and low nutrient availability are common. In marine systems, the addition of nutrients, e.g., in the form of nitrogen-rich fertilizers from agricultural runoffs, can greatly change the once oligotrophic environment into a copitrophic one, leading to harmful large scale phytoplanktonic blooms (Beman et al., 2005). Depending on concentrations of nutrients, populations of free-living smallcelled microorganisms can either be enriched in R-strategists, or in K-strategists playing distinct roles in the community. K-strategists, e.g., SUP05 clade and "Ca. P. ubique," are heavily involved with carbon and nitrogen cycling in oligotrophic areas (such as the open ocean and oxygen-depleted zones) (Giovannoni, 2017; Rogge et al., 2017). They are slow-growing and are widely dispersed, and rarely form colonies (Dang and Lovell, 2016; Giovannoni, 2017; Roshan and DeVries, 2017). R-strategists, e.g., Marine Roseobacter Clade (MRC) members and Bacteroidetes, are widely distributed and typically reside in nutrient-rich systems, e.g., in coastal systems (Dang and Lovell, 2016). These free-living organisms under favorable conditions grow quickly and may form large densely packed colonies and biofilms (Dang and Lovell, 2016). MRC bacteria can produce auxins and vitamins that are beneficial for algae (Dang and Lovell, 2016), whereas catabolically versatile Bacteriodetes play key roles in degrading high molecular weight DOM and biopolymers (Dang and Lovell, 2016).

In vertebrate systems, the role of these organisms appears variable. As seen in the case of TM7x, it may be beneficial or harmful to the host. Actinomyces strain XH001 normally elicits an immune response but TM7x modulates this response by either suppressing TNF- $\alpha$ gene expression in macrophages or "masking" it from macrophage detection altogether. However, under extended starvation conditions, TM7x can turn parasite, which leads to the host's demise (He et al., 2015).

Much of the literature discussed in this review has focused on a few species, however, the concerted effect of the entire ultra-small-sized microbial community in ecosystem functioning remains unknown. As discussed earlier, filtration through $<0.45 \mu \mathrm{m}$ pore size filters, is a common method to isolate small cells from aqueous samples. Interestingly, ultrafiltration was considered a method of choice to preserve freshwater samples during their storage and prior the hydrochemistry 
analysis (Brailsford et al., 2017). $0.22 \mu \mathrm{m}$ pore size filters were considered as a safe tool for sterilization and for effective removal of microorganisms. However, a recent study, which monitored the depletion of ${ }^{14} \mathrm{C}$-glucose, ${ }^{14} \mathrm{C}$-amino acid mixture, and ${ }^{33} \mathrm{P}$ orthophosphate in filtered and unfiltered freshwater samples showed significant activity and utilization of substrates by organisms capable of passing this barrier (Brailsford et al., 2017). The previous studies clearly support this claim, as a number of the species were able to pass through ultrafiltration membranes (e.g., Wang et al., 2008). The great abundance of small-sized organisms in aqueous environments may also be attributed to selective pressures of predator-prey-viral interactions (Salcher, 2014). As discussed, protists feed on bacterioplankton and select prey based on cell size (Pernthaler et al., 2001; Salcher et al., 2013; Pernthaler, 2017). Conversely, viruses select for highdensity preys and promote generation of DOM from lysed cells (Salcher, 2014), which can then be utilized by nano-sized microorganisms.

Nutrient cycling by ultra-small-sized organisms is not restricted to aquatic environments. A number of studies have shown an active population of ultramicrobacteria within a wide range of soil types (Soina et al., 2012; Lysak et al., 2013; Dobrovol'skaya et al., 2015). It was previously thought that soil pores $<1 \mu \mathrm{m}$ would be inaccessible to cells, leading to physical protection of organic carbon in soil. However, the potential of small-sized organisms to occupy this void space alongside their functional significance in soil remain unknown.

\section{CONCLUSION AND OUTLOOK}

Discovery of small cells in the environment has reshaped our understanding of the microbial world and life on this planet. Using culture-independent tools first insights into the functionality of these organisms and a precise definition of

\section{REFERENCES}

Albertsen, M., Hugenholtz, P., Skarshewski, A., Nielsen, K. L., Tyson, G. W., and Nielsen, P. H. (2013). Genome sequences of rare, uncultured bacteria obtained by differential coverage binning of multiple metagenomes. Nat. Biotechnol. 31, 533-538. doi: 10.1038/nbt.2579

Azam, F., Fenchel, T., Field, J. G., Gray, J. S., Meyer-Reil, L. A., and Thingstad, F. (1983). The ecological role of water - column microbes in the sea. Mar. Ecol. Prog. Ser. 10, 257-263. doi: 10.3354/meps010257

Baker, B. J., and Banfield, J. F. (2003). Microbial communities in acid mine drainage. FEMS Microbiol. Ecol. 44, 139-152. doi: 10.1016/S0168-6496(03) 00028-X

Baker, B. J., Comolli, L. R., Dick, G. J., Hauser, L. J., Hyatt, D., Dill, B. D., et al. (2010). Enigmatic, ultrasmall, uncultivated Archaea. Proc. Natl. Acad. Sci. U.S.A. 107, 8806-8811. doi: 10.1073/pnas.0914470107

Baker, B. J., Tyson, G. W., Webb, R. I., Flanagan, J., Hugenholtz, P., Allen, E. E., et al. (2006). Lineages of acidophilic Archaea revealed by community genomic analysis. Science 314, 1933-1935. doi: 10.1126/science.1132690

Beman, J. M., Arrigo, K. R., and Matson, P. A. (2005). Agricultural runoff fuels large phytoplankton blooms in vulnerable areas of the ocean. Nature 434, 211-214. doi: $10.1038 /$ nature 03370

Brailsford, F. L., Glanville, H. C., Marshall, M. R., Golyshin, P. N., Johnes, P. J., Yates, C. A., et al. (2017). Microbial use of low molecular weight DOM in filtered and unfiltered freshwater: role of ultra-small microorganisms and implications the minimal sizes of living forms have been gained. Hence, it is reasonable to think that small-sized organisms may play a significant role in many environments. Many studies performed to date, however, have not considered the functionality of these organisms. Future studies should therefore shift their focus to understanding their physiology and function. As more ecosystems are explored and as techniques are improved, the possibility of finding small-sized organisms is increasing. Culture- independent analysis will remain a critical tool for modeling and predicting functionalities and abundance of these organisms, however, the functional analysis of their activities remains essential to validate genome-based predictions.

\section{AUTHOR CONTRIBUTIONS}

All authors conceived the review. L-AG searched the literature, synthesized the data, and wrote the manuscript. DJ, PG, and OG provided significant revisions to the manuscript including data interpretation and writing parts of the manuscript. All authors read the final manuscript.

\section{FUNDING}

This work was carried out under the DOMAINE project, which is funded by the United Kingdom Natural Environment Research Council (NERC) (large Grant No. NE/K010689/1). OG and PG acknowledge the support of the Centre of Environmental Biotechnology Project part-funded by the European Regional Development Fund (ERDF) through the Welsh Government and thank the European Union Horizon 2020 Research and Innovation Program (Blue Growth: Unlocking the Potential of Seas and Oceans, Grant Agreement No. 634486, Project acronym 'INMARE') for its support.

for water quality monitoring. Sci. Total Environ. 598, 377-384. doi: 10.1016/j. scitotenv.2017.04.049

Button, D. K., Robertson, B. R., Lepp, P. W., and Schmidt, T. M. (1998). A small, dilute-cytoplasm, high-affinity, novel bacterium isolated by extinction culture and having kinetic constants compatible with growth at ambient concentrations of dissolved nutrients in seawater. Appl. Environ. Microbiol. 64, 4467-4476.

Caporaso, J. G., Lauber, C. L., Walters, W. A., Berg-Lyons, D., Lozupone, C. A., Turnbaugh, P. J., et al. (2011). Global patterns of 16S rRNA diversity at a depth of millions of sequences per sample. Proc. Natl. Acad. Sci. U.S.A. 108, 4516-4522. doi: 10.1073/pnas. 1000080107

Carini, P., Steindler, L., Beszteri, S., and Giovannoni, S. J. (2012). Nutrient requirements for growth of the extreme oligotroph 'Candidatus Pelagibacter ubique' HTCC1062 on a defined medium. ISME J. 7, 592-602. doi: 10.1038/ ismej.2012.122

Cesar, S., and Huang, K. C. (2017). Thinking big: the tunability of bacterial cell size. FEMS Microbiol. Rev. 41, 672-678. doi: 10.1093/femsre/fux026

Chien, A. C., Hill, N. S., and Levin, P. A. (2012). Cell size control in bacteria. Curr. Biol. 22, R340-R349. doi: 10.1016/j.cub.2012.02.032

Cisar, J. O., Xu, D. Q., Thompson, J., Swaim, W., Hu, L., and Kopecko, D. J. (2000). An alternative interpretation of nanobacteria-induced biomineralization. Proc. Natl. Acad. Sci. U.S.A. 97, 11511-11515. doi: 10.1073/pnas.97.21.11511

Comolli, L. R., Baker, B. J., Downing, K. H., Siegerist, C. E., and Banfield, J. F. (2009). Three-dimensional analysis of the structure and ecology of a novel, ultra-small archaeon. ISME J. 3, 159-167. doi: 10.1038/ismej.2008.99 
Comolli, L. R., and Banfield, J. F. (2014). Inter-species interconnections in acid mine drainage microbial communities. Front. Microbiol. 5:367. doi: 10.3389/ fmicb.2014.00367

Dang, H., and Lovell, C. R. (2016). Microbial surface colonization and biofilm development in marine environments. Microbiol. Mol. Biol. Rev. 80, 91-138. doi: 10.1128/MMBR.00037-15

Dobrovol'skaya, T. G., Zvyagintsev, D. G., Chernov, I. Y., Golovchenko, A. V., Zenova, G. M., Lysak, L. V., et al. (2015). The role of microorganisms in the ecological functions of soils. Eurasian Soil Sci. 48, 959-967. doi: 10.1134/ S1064229315090033

Duda, V. I., Suzina, N. E., Polivtseva, V. N., and Boronin, A. M. (2012). Ultramicrobacteria: formation of the concept and contribution of ultramicrobacteria to biology. Microbiology 81, 379-390. doi: 10.1134/ S0026261712040054

Fedotova, A. V., Belova, S. E., Kulichevskaya, I. S., and Dedysh, S. N. (2012). Molecular identification of filterable bacteria and Archaea in the water of acidic lakes of northern Russia. Microbiology 81, 281-287. doi: 10.1134/ S002626171203006X

Fenchel, T. (1982). Ecology of heterotrophic microflagellates. I. Some important forms and their functional morphology. Mar. Ecol. Prog. Ser. 8, 211-223. doi: $10.3354 /$ meps008211

Garza, D. R., and Dutilh, B. E. (2015). From cultured to uncultured genome sequences: metagenomics and modeling microbial ecosystems. Cell. Mol. Life Sci. 72, 4287-4308. doi: 10.1007/s00018-015-2004-1

Gasol, J. M., and Morán, X. A. G. (1999). Effects of filtration on bacterial activity and picoplankton community structure as assessed by flow cytometry. Aquat. Microb. Ecol. 16, 251-264. doi: 10.3354/ame016251

Giannone, R. J., Wurch, L. L., Heimerl, T., Martin, S., Yang, Z., Huber, H., et al. (2014). Life on the edge: functional genomic response of Ignicoccus hospitalis to the presence of Nanoarchaeum equitans. ISME J. 9, 101-114. doi: 10.1038/ismej. 2014.112

Gibson, E. K., McKay, D. S., Thomas-Keprta, K. L., Wentworth, S. J., Westall, F., Steele, A., et al. (2001). Life on mars: evaluation of the evidence within martian meteorites ALH84001, Nakhla, and Shergotty. Precambrian Res. 106, 15-34. doi: 10.1016/S0301-9268(00)00122-4

Giovannoni, S. J. (2017). SAR11 bacteria: the most abundant plankton in the oceans. Ann. Rev. Mar. Sci. 9, 231-255. doi: 10.1146/annurev-marine-010814015934

Giovannoni, S. J., Cameron Thrash, J., and Temperton, B. (2014). Implications of streamlining theory for microbial ecology. ISME J. 8, 1-13. doi: 10.1038/ismej. 2014.60

Giovannoni, S. J., Tripp, H. J., Givan, S., Podar, M., Vergin, K. L., Baptista, D., et al. (2005). Genome streamlining in a cosmopolitan oceanic bacterium. Science 309, 1242-1245. doi: 10.1126/science. 1114057

Glaubitz, S., Kießlich, K., Meeske, C., Labrenz, M., and Jürgens, K. (2013). SUP05 dominates the gammaproteobacterial sulfur oxidizer assemblages in pelagic redoxclines of the central baltic and black seas. Appl. Environ. Microbiol. 79, 2767-2776. doi: 10.1128/AEM.03777-12

Glissmann, K., Chin, K. J., Casper, P., and Conrad, R. (2004). Methanogenic pathway and archaeal community structure in the sediment of eutrophic Lake Dagow: effect of temperature. Microb. Ecol. 48, 389-399. doi: 10.1007/s00248003-2027-2

Golyshina, O. V. (2014). "The family Ferroplasmaceae," in The Prokaryotes, eds E. Rosenberg, E. F. DeLong, S. Lory, E. Stackebrandt, and F. Thompson (Berlin: Springer), 29-34.

Golyshina, O. V., Lünsdorf, H., Kublanov, I. V., Goldenstein, N. I., Hinrichs, K. U., and Golyshin, P. N. (2016). The novel extremely acidophilic, cell-walldeficient archaeon Cuniculiplasma divulgatum gen. nov., sp. nov. represents a new family, Cuniculiplasmataceae fam. nov., of the order Thermoplasmatales. Int. J. Syst. Evol. Microbiol. 66, 332-340. doi: 10.1099/ijsem.0.000725

Golyshina, O. V., Toshchakov, S. V., Makarova, K. S., Gavrilov, S. N., Korzhenkov, A. A., La Cono, V., et al. (2017). "ARMAN" Archaea depend on association with euryarchaeal host in culture and in situ. Nat. Commun. 8:60. doi: 10.1038/ s41467-017-00104-7

Hahn, M. W., Lünsdorf, H., Wu, Q., Höfle, M. G., Boenigk, J., Stadler, P., et al. (2003). Isolation of novel ultramicrobacteria classified as actinobacteria from five freshwater habitats in Europe and Asia isolation of novel ultramicrobacteria classified as actinobacteria from five freshwater habitats in Europe and
Asia. Appl. Environ. Microbiol. 69, 1442-1451. doi: 10.1128/AEM.69. 3.1442

Hansell, D. A., Carlson, C. A., Repeta, D. J., and Schlitzer, R. (2009). Dissolved organic matter in the ocean. Oceanography 22, 202-211. doi: 10.1038/ ncomms 8422

He, X., McLean, J. S., Edlund, A., Yooseph, S., Hall, A. P., Liu, S.-Y., et al. (2015). Cultivation of a human-associated TM7 phylotype reveals a reduced genome and epibiotic parasitic lifestyle. Proc. Natl. Acad. Sci. U.S.A. 112, 244-249. doi: 10.1073/pnas.1419038112

Hodson, A., Anesio, A. M., Tranter, M., Fountain, A., Osborn, M., Priscu, J., et al. (2008). Glacial ecosystems. Ecol. Monogr. 78, 41-67. doi: 10.1002/ecm.1283

Huber, H., Hohn, M. J., Rachel, R., Fuchs, T., Wimmer, V. C., and Stetter, K. O. (2002). A new phylum of Archaea represented by a nanosized hyperthermophilic symbiont. Nature 417, 63-67. doi: 10.1038/417063a

Ishoey, T., Woyke, T., Stepanauskas, R., Novotny, M., and Lasken, R. S. (2008). Genomic sequencing of single microbial cells from environmental samples. Curr. Opin. Microbiol. 11, 198-204. doi: 10.1016/j.mib.2008.05.006

Jahn, U., Gallenberger, M., Paper, W., Junglas, B., Eisenreich, W., Stetter, K. O., et al. (2008). Nanoarchaeum equitans and Ignicoccus hospitalis: new insights into a unique, intimate association of two Archaea. J. Bacteriol. 190, 1743-1750. doi: 10.1128/JB.01731-07

Johnson, K. S., Gordon, R. M., and Coale, K. H. (1997). What controls dissolved iron concentrations in the world ocean? Mar. Chem. 57, 137-161. doi: 10.1016/ S0304-4203(97)00043-1

Kajander, E. O., and Ciftcioglu, N. (1998). Nanobacteria: an alternative mechanism for pathogenic intra- and extracellular calcification and stone formation. Proc. Natl. Acad. Sci. U.S.A. 95, 8274-8279. doi: 10.1073/pnas.95.14.8274

Kajander, E. O., Ciftcioglu, N., Aho, K., and Garcia-Cuerpo, E. (2003). Characteristics of nanobacteria and their possible role in stone formation. Urol. Res. 31, 47-54. doi: 10.1007/s00240-003-0304-7

Kantor, R. S., Wrighton, K. C., Handley, K. M., Sharon, I., Hug, L. A., Castelle, C. J., et al. (2013). Small genomes and sparse metabolisms of sediment-associated bacteria from four candidate phyla. mBio 4:e00708-13. doi: 10.1128/mBio. 00708-13

Krogh, A., Larsson, B., Von Heijne, G., and Sonnhammer, E. L. L. (2001). Predicting transmembrane protein topology with a hidden Markov model: application to complete genomes. J. Mol. Biol. 305, 567-580. doi: 10.1006/jmbi.2000.4315

Kuczynski, J., Liu, Z., Lozupone, C., McDonald, D., Fierer, N., and Knight, R. (2010). Microbial community resemblance methods differ in their ability to detect biologically relevant patterns. Nat. Methods 7, 813-819. doi: 10.1038/ nmeth.1499

Leiman, P. G., Kanamaru, S., Mesyanzhinov, V. V., Arisaka, F., and Rossmann, M. G. (2003). Structure and morphogenesis of bacteriophage T4. Cell. Mol. Life Sci. 60, 2356-2370. doi: 10.1007/s00018-003-3072-1

Lever, M. A., Rogers, K. L., Lloyd, K. G., Overmann, J., Schink, B., Thauer, R. K., et al. (2015). Life under extreme energy limitation: a synthesis of laboratoryand field-based investigations. FEMS Microbiol. Rev. 39, 688-728. doi: 10.1093/ femsre/fuv020

Luef, B., Frischkorn, K. R., Wrighton, K. C., Holman, H.-Y. N., Birarda, G., Thomas, B. C., et al. (2015). Diverse uncultivated ultra-small bacterial cells in groundwater. Nat. Commun. 6:6372. doi: 10.1038/ncomms7372

Lysak, L. V., Kadulin, M. S., Konova, I. A., Lapygina, E. V., Ivanov, A. V., and Zvyagintsev, D. G. (2013). Population number, viability, and taxonomic composition of the bacterial nanoforms in iron-manganic concretions. Eurasian Soil Sci. 46, 668-675. doi: 10.1134/S1064229313060069

Ma, D., Hao, Z., Sun, R., Bartlam, M., and Wang, Y. (2016). Genome sequence of a typical ultramicrobacterium, Curvibacter strain PAE-UM, capable of phthalate ester degradation. Genome Announc. 4, 1-2. doi: 10.1128/genomeA.01510-15

Martínez-Cano, D. J., Reyes-Prieto, M., Martínez-Romero, E., Partida-Martínez, L. P., Latorre, A., Moya, A., et al. (2015). Evolution of small prokaryotic genomes. Front. Microbiol. 6:742. doi: 10.3389/fmicb.2014.00742

McCutcheon, J. P., and Moran, N. A. (2011). Extreme genome reduction in symbiotic bacteria. Nat. Rev. Microbiol. 10, 13-26. doi: 10.1038/nrmicro 2670

McKay, D. S., Gibson, E. K., Thomas-Keprta, K. L., Vali, H., Romanek, C. S. Clemett, S. J., et al. (1996). Search for past life on Mars: possible relic biogenic activity in martian meteorite ALH84001. Science 273, 924-930. doi: 10.1126/ science.273.5277.924 
Miteva, V. (2008). "Bacteria in snow and glacier ice," in Psychrophiles: From Biodiversity to Biotechnology, eds R. Margesin, F. Schinner, J. C. Marx, and C. Gerday (Berlin: Springer), 31-50. doi: 10.1007/978-3-540-74335-4_3

Miteva, V. I., and Brenchley, J. E. (2005). Detection and isolation of ultrasmall microorganisms from a. Appl. Environ. Microbiol. 71, 7806-7818. doi: 10.1128/ AEM.71.12.7806

Möller, S., Croning, M. D. R., and Apweiler, R. (2001). Evaluation of methods for the prediction of membrane spanning regions. Bioinformatics 17, 646-653. doi: 10.1093/bioinformatics/17.7.646

Monier, J.-M., and Lindow, S. E. (2003). Pseudomonas syringae responds to the environment on leaves by cell size reduction. Phytopathology 93, 1209-1216. doi: 10.1094/PHYTO.2003.93.10.1209

Morris, R. M., Rappé, M. S., Connon, S. A., Vergin, K. L., Siebold, W. A., Carlson, C. A., et al. (2002). SAR11 clade dominates ocean surface bacterioplankton communities. Nature 420, 806-810. doi: 10.1038/nature01240

Munson-McGee, J. H., Field, E. K., Bateson, M., Rooney, C., Stepanauskas, R., and Young, M. J. (2015). Nanoarchaeota, their Sulfolobales host, and Nanoarchaeota virus distribution across Yellowstone National Park hot springs. Appl. Environ. Microbiol. 81, 7860-7868. doi: 10.1128/AEM.01539-15

Mushegian, A. R., and Koonin, E. V. (1996). A minimal gene set for cellular life derived by comparison of complete bacterial genomes. Proc. Natl. Acad. Sci. U.S.A. 93, 10268-10273. doi: 10.1073/pnas.93.19.10268

Nagy, I., Knispel, R. W., Kofler, C., Orsini, M., Boicu, M., Varga, S., et al. (2016). Lipoprotein-like particles in a prokaryote: quinone droplets of Thermoplasma acidophilum. FEMS Microbiol. Lett. 363, 1-7. doi: 10.1093/femsle/fnw169

Nakai, R., Fujisawa, T., Nakamura, Y., Nishide, H., Uchiyama, I., Baba, T., et al. (2016). Complete genome sequence of Aurantimicrobium minutum type strain $\mathrm{KNC}$, a planktonic ultramicrobacterium isolated from river water. Genome Announc. 4, e00616-16. doi: 10.1128/genomeA.00616-16

Narasingarao, P., Podell, S., Ugalde, J. A., Brochier-Armanet, C., Emerson, J. B., Brocks, J. J., et al. (2012). De novo metagenomic assembly reveals abundant novel major lineage of Archaea in hypersaline microbial communities. ISME J. 6, 81-93. doi: 10.1038/ismej.2011.78

Neuenschwander, S. M., Salcher, M. M., and Pernthaler, J. (2015). Fluorescence in situ hybridization and sequential catalyzed reporter deposition (2C-FISH) for the flow cytometric sorting of freshwater ultramicrobacteria. Front. Microbiol. 6:247. doi: 10.3389/fmicb.2015.00247

Oppenheimer, C. H. (1952). The membrane filter in marine microbiology. J. Bacteriol. 64, 783-786.

Panikov, N. S. (2005). Contribution of Nanosized Bacteria to the total biomass and activity of a soil microbial community. Adv. Appl. Microbiol. 57, 245-296. doi: 10.1016/S0065-2164(05)57008-4

Pernthaler, J. (2017). Competition and niche separation of pelagic bacteria in freshwater habitats. Environ. Microbiol. 19, 2133-2150. doi: 10.1111/1462-2920. 13742

Pernthaler, J., Posch, T., Šimek, K., Vrba, J., Pernthaler, A., Glöckner, F. O., et al. (2001). Predator-specific enrichment of actinobacteria from a cosmopolitan freshwater clade in mixed continuous culture. Appl. Environ. Microbiol. 67, 2145-2155. doi: 10.1128/AEM.67.5.2145

Podar, M., Makarova, K. S., Graham, D. E., Wolf, Y. I., Koonin, E. V., and Reysenbach, A.-L. (2013). Insights into archaeal evolution and symbiosis from the genomes of a nanoarchaeon and its inferred crenarchaeal host from Obsidian Pool, Yellowstone National Park. Biol. Direct 8:9. doi: 10.1186/17456150-8-9

Probst, A. J., Ladd, B., Jarett, J. K., Geller-Mcgrath, D. E., Sieber, C. M. K., Emerson, J. B., et al. (2018). Differential depth distribution of microbial function and putative symbionts through sediment-hosted aquifers in the deep terrestrial subsurface. Nat. Microbiol. 3, 328-336. doi: 10.1038/s41564-017-0098-y

Rappé, M. S., Connon, S. A., Vergin, K. L., and Giovannoni, S. J. (2002). Cultivation of the ubiquitous SAR11 marine bacterioplankton clade. Nature 418, 630-633. doi: $10.1038 /$ nature00917

Rogge, A., Vogts, A., Voss, M., Jürgens, K., Jost, G., and Labrenz, M. (2017). Success of chemolithoautotrophic SUP05 and sulfurimonas GD17 cells in pelagic Baltic Sea redox zones is facilitated by their lifestyles as K- and r-strategists. Environ. Microbiol. 19, 2495-2506. doi: 10.1111/1462-2920.13783

Roshan, S., and DeVries, T. (2017). Efficient dissolved organic carbon production and export in the oligotrophic ocean. Nat. Commun. 8:2036. doi: 10.1038/ s41467-017-02227-3
Salcher, M. M. (2014). Same same but different: ecological niche partitioning of planktonic freshwater prokaryotes. J. Limnol. 73, 74-87. doi: 10.4081/jlimnol. 2014.813

Salcher, M. M., Posch, T., and Pernthaler, J. (2013). In situ substrate preferences of abundant bacterioplankton populations in a prealpine freshwater lake. ISME J. 7, 896-907. doi: 10.1038/ismej.2012.162

Sauzède, R., Bittig, H. C., Claustre, H., Pasqueron de Fommervault, O., Gattuso, J.-P., Legendre, L., et al. (2017). Estimates of water-column nutrient concentrations and carbonate system parameters in the global ocean: a novel approach based on neural networks. Front. Mar. Sci. 4:128. doi: 10.3389/fmars. 2017.00128

Schulz, H. N., and Jørgensen, B. B. (2001). Big Bacteria. Annu. Rev. Microbiol. 55, 105-137. doi: 10.1146/annurev.micro.55.1.105

Schut, F., Jansen, M., Pedro Gomes, T. M., Gottschal, J. C., Harder, W., and Prins, R. A. (1995). Substrate uptake and utilization by a marine ultramicrobacterium. Microbiology 141, 351-361. doi: 10.1099/13500872-141-2-351

Schut, F., Prins, R. A., and Gottschal, J. C. (1997). Oligotrophy and pelagic marine bacteria: facts and fiction. Aquat. Microb. Ecol. 12, 177-202. doi: 10.3354/ ame012177

Shah, V., Chang, B. X., and Morris, R. M. (2017). Cultivation of a chemoautotroph from the SUP05 clade of marine bacteria that produces nitrite and consumes ammonium. ISME J. 11, 263-271. doi: 10.1038/ismej.2016.87

Sieburth, J. M. N., Smetacek, V., and Lenz, J. (1978). Pelagic ecosystem structure: heterotrophic compartments of the plankton and their relationship to plankton size fractions. Limnol. Oceanogr. 23, 1256-1263. doi: 10.4319/lo.1978.23.6.1256

Simon, M., Grossart, H. P., Schweitzer, B., and Ploug, H. (2002). Microbial ecology of organic aggregates in aquatic ecosystems. Aquat. Microb. Ecol. 28, 175-211. doi: 10.3354/ame028175

Soina, V. S., Lysak, L. V., Konova, I. A., Lapygina, E. V., and Zvyagintsev, D. G. (2012). Study of ultramicrobacteria (\{Nanoforms\}) in soils and subsoil deposits by electron microscopy. Eurasian Soil Sci. 45, 1048-1056. doi: 10.1134/ S1064229312110087

Stevens, T., and Arkin, I. (2000). Do more complex organisms have a greater proportion of membrane proteins in their genomes. Proteins 39, 417-420. doi: 10.1002/(SICI)1097-0134(20000601)39:4<417::AID-PROT140>3.0.CO;2$\mathrm{Y}$

Suzina, N. E., Esikova, T. Z., Oleinikov, R. R., Gafarov, A. B., Shorokhova, A. P., Polivtseva, V. N., et al. (2015). Comparative characteristics of free-living ultramicroscopical bacteria obtained from natural biotopes. Microbiology 51, 159-168. doi: 10.1134/S0003683815020192

Tagliabue, A., Bowie, A. R., Boyd, P. W., Buck, K. N., Johnson, K. S., and Saito, M. A. (2017). The integral role of iron in ocean biogeochemistry. Nature 543, 51-59. doi: $10.1038 /$ nature21058

Thompson, L. R., Sanders, J. G., McDonald, D., Amir, A., Ladau, J., Locey, K. J., et al. (2017). A communal catalogue reveals Earth's multiscale microbial diversity. Nature 551, 457-463. doi: 10.1038/nature24621

Torrella, F., and Morita, R. Y. (1981). Microcultural study of bacterial size changes and microcolony and ultramicrocolony formation by heterotropic bacteria in seawater. Appl. Environ. Microbiol. 41, 518-527.

Torsvik, V., and Øvreås, L. (2008). "Microbial diversity, life strategies, and adaptation to life in extreme soils," in Microbiology of Extreme Soils. Soil Biology, Vol. 13, eds P. Dion and C. S. Nautiyal (Berlin: Springer), 15-43. doi: 10.1007/ 978-3-540-74231-9

Tringe, S. G., von Mering, C., Kobayashi, A., Salamov, A. A., Chen, K., Chang, H. W., et al. (2005). Comparative metagenomics of microbial communities. Science 308, 554-557. doi: 10.1126/science. 1107851

Tripp, H. J. (2013). The unique metabolism of SAR11 aquatic bacteria. J. Microbiol. 51, 147-153. doi: 10.1007/s12275-013-2671-2

Vancanneyt, M., Schut, F., Snauwaert, C., Goris, J., Swings, J., and Gottschal, J. C. (2001). Sphingomonas alaskensis sp. now., a dominant bacterium from a marine oligotrophic environment. Int. J. Syst. Evol. Microbiol. 51, 73-80. doi: 10.1099/00207713-51-1-73

Velimirov, B. (2001). Nanobacteria, ultramicrobacteria and starvation forms: a search for the smallest metabolizing bacterium. Microbes Environ. 16, 67-77. doi: 10.1264/jsme2.2001.67

Venter, J. C., Remington, K., Heidelberg, J. F., Halpern, A. L., Rusch, D., Eisen, J. A., et al. (2004). Environmental genome shotgun sequencing of the Sargasso Sea. Science 304, 66-74. doi: 10.1126/science. 1093857 
Vergin, K. L., Done, B., Carlson, C. A., and Giovannoni, S. J. (2013). Spatiotemporal distributions of rare bacterioplankton populations indicate adaptive strategies in the oligotrophic ocean. Aquat. Microb. Ecol. 71, 1-13. doi: 10.3354/ame01661

Wagner, J. K., Setayeshgar, S., Sharon, L. A., Reilly, J. P., and Brun, Y. V. (2006). A nutrient uptake role for bacterial cell envelope extensions. Proc. Nat. Acad. Sci. U.S.A. 103, 11772-11777. doi: 10.1073/pnas.0602047103

Wang, Y., Hammes, F., Boon, N., and Egli, T. (2007). Quantification of the filterability of freshwater bacteria through $0.45,0.22$, and $0.1 \mu \mathrm{m}$ pore size filters and shape-dependent enrichment of filterable bacterial communities. Environ. Sci. Technol. 41, 7080-7086. doi: 10.1021/es0707198

Wang, Y., Hammes, F., Düggelin, M., and Egli, T. (2008). Influence of size, shape, and flexibility on bacterial passage through micropore membrane filters. Environ. Sci. Technol. 42, 6749-6754. doi: 10.1021/es800720n

Waters, E., Hohn, M. J., Ahel, I., Graham, D. E., Adams, M. D., Barnstead, M., et al. (2003). The genome of Nanoarchaeum equitans: insights into early archaeal evolution and derived parasitism. Proc. Natl. Acad. Sci. U.S.A. 100, 12984-12988. doi: 10.1073/pnas.1735403100

Watson, S. P., Clements, M. O., and Foster, S. J. (1998). Characterization of the starvation-survival response of Staphylococcus aureus. J. Bacteriol. 180, 1750-1758.

Weinbauer, M. G. (2004). Ecology of prokaryotic viruses. FEMS Microbiol. Rev. 28, 127-181. doi: 10.1016/j.femsre.2003.08.001

Winter, C., Bouvier, T., Weinbauer, M. G., and Thingstad, T. F. (2010). Tradeoffs between competition and defense specialists among unicellular planktonic organisms: the "killing the winner" hypothesis revisited. Microbiol. Mol. Biol. Rev. 74, 42-57. doi: 10.1128/MMBR.00034-09

Wrighton, K. C., Thomas, B. C., Sharon, I., Miller, C. S., Castelle, C. J., VerBerkmoes, N. C., et al. (2012). Fermentation, hydrogen, and sulfur metabolism in multiple uncultivated bacterial phyla (supplement materials). Science 337, 1661-1665. doi: 10.1126/science.1224041

Wu, X., Holmfeldt, K., Hubalek, V., Lundin, D., Åström, M., Bertilsson, S., et al. (2015). Microbial metagenomes from three aquifers in the Fennoscandian shield terrestrial deep biosphere reveal metabolic partitioning among populations. ISME J. 10, 1192-1203. doi: 10.1038/ismej.2015.185

Wurch, L., Giannone, R. J., Belisle, B. S., Swift, C., Utturkar, S., Hettich, R. L., et al. (2016). Genomics-informed isolation and characterization of a symbiotic Nanoarchaeota system from a terrestrial geothermal environment. Nat. Commun. 7:12115. doi: 10.1038/ncomms 12115

Young, K. D. (2006). The selective value of bacterial shape. Microbiol. Mol. Biol. Rev. 70, 660-703. doi: 10.1128/MMBR.00001-06

Zhao, X., Schwartz, C. L., Pierson, J., Giovannoni, S. J., Mcintosh, J. R., and Nicastro, D. (2017). Three-dimensional structure of the ultraoligotrophic marine bacterium "Candidatus pelagibacter ubique. Appl. Environ. Microbiol. 83, 1-14. doi: 10.1128/AEM.02807-16

Conflict of Interest Statement: The authors declare that the research was conducted in the absence of any commercial or financial relationships that could be construed as a potential conflict of interest.

Copyright (c) 2018 Ghuneim, Jones, Golyshin and Golyshina. This is an open-access article distributed under the terms of the Creative Commons Attribution License (CC BY). The use, distribution or reproduction in other forums is permitted, provided the original author(s) and the copyright owner(s) are credited and that the original publication in this journal is cited, in accordance with accepted academic practice. No use, distribution or reproduction is permitted which does not comply with these terms. 